DOI: https://doi.org/10.24127/ajpm.v8i1.1733

\title{
ANALISIS TINGKAT KEMAMPUAN BERPIKIR KREATIF MATEMATIS PESERTA DIDIK DITINJAU DARI GAYA BELAJAR KELAS VII SMP
}

\author{
Dwi Purwanti ${ }^{1}$, Jamal Fakhri ${ }^{2}$, Hasan Sastra Negara ${ }^{3}$ \\ ${ }^{1,2,3}$ Pendidikan Matematika, Universitas Islam Negeri Raden Intan Lampung \\ E-mail: dwip9774@gmail.com $^{1)}$ \\ jamal_fakhri63@yahoo.com ${ }^{2}$ \\ hasansastranegara@radenintan.ac.id ${ }^{3)}$
}

Received 17 December 2018; Received in revised form 1 April 2019; Accepted 3 May 2019

\begin{abstract}
This research is motivated by observations at Muhammadiyah junior high school number 3 in Bandar Lampung that ability of students to solve mathematical problems have different thinking skills, diverse learning styles possessed by students in absorbing and processing information while the learning process is taking place and educators have never tested specifically creative thinking and learning styles. The purpose of this research is to determine the level of mathematical creative thinking abilities of students as seen from the visual, auditory and kinesthetic learning styles by Muhammadiyah junior high school number 3 in Bandar Lampung. Subjects for this research were conducted in VIIB and VIIE classes by taking subjects by purposive sampling, namely 2 subjects of visual learning style, 2 subjects in auditory learning styles and 2 subjects of kinesthetic learning styles. The results of this research is to indicate that students with visual learning styles are classified as level 1(less creative), students with auditorial learning styles are classified as level 1(less creative) and kinesthetic learning is classified as level 1(less creative) and as level 3(creative).
\end{abstract}

Keywords: Creative Thinking; Learning Style; Level of Mathematical Creative Thinking Ability.

\section{PENDAHULUAN}

Kreativitas

merupakan

kompetensi yang dimiliki oleh seseorang untuk membuat gabungangabungan sebagai hasil kreativitasnya yang baru dan memiliki makna sosial, tidak semua yang dihasilkan itu harus baru, melainkan gabungangabungannya. Dengan menggabungkan bagian-bagian yang telah ada sebelumnya maka akan diperolehlah kombinasi yang baru (Munandar, 2012). Career Center Maine Departmen of Labor USA berpendapat bahwa salah satu kemampuan yang dibutuhkan dalam dunia kerja adalah kemampuan berpikir kreatif (Mursidik, Samsiyah, \& Rudyanto, 2015). Akan tetapi bukan bidang pekerjaan saja yang memerlukan pemikiran kreatif melainkan bidang pendidikan pula khususnya dalam pendidikan matematika, karena berpikir kreatif merupakan tujuan pembelajaran matematika itu sendiri. (Anggoro, 2015).

Menurut Pohken bahwa dalam belajar matematika munculnya pemikiran yang kreatif adalah dengan menggabungkan berpikir logis dan divergen dimana dalam kegiatan berpikirnya mampu menjukan indikator berpikir kreatif (Alhaddad, 2013). Berpikir kreatif adalah aktivitas mental manusia dalam memecahkan masalah matematika dengan kemampuan menemukan banyak kemungkinan jawaban atau menemukan satu jawaban yang sama tetapi dengan banyak cara yang berbeda (Fardah, 2012).

Berdasarkan hasil observasi dan wawancara terhadap salah satu pendidik mata pelajaran matematika di SMP 
Muhammadiyah 3 Bandar Lampung terlihat pada beberapa peserta didik bahwa dalam menyelesaikan soal matematika mereka memiliki kemampuan yang berbeda dimulai dari cara pengerjaannya, proses perhitungannya, dan jawaban yang dihasilkan berbeda pula. Hal ini dapat menunjukan bahwa terdapat cara berpikir yang berbeda sehingga tingkat kreatifitas dalam memecahkan soalpun pasti berbeda. Selain itu, saat dalam kegiatan pembelajaran berlangsung peserta didik menunjukkan karakterkarakter yang beragam, ada peserta didik yang selalu semangat dalam belajar, malas dalam belajar, dan ada peserta didik selalu tekun dan patuh terhadap perintah pendidik. Ketika ditanyakan kepada salah satu pendidik tersebut bahwa pendidik belum mengetahui tingkat kreatifitas peserta didik saat memecahkan masalah matematika terdapat di level yang mana dan pendidik pula belum mengetahui karakter-karakter yang ada peserta didik termasuk kedalam jenis gaya belajar apa. Hal ini dikarenakan pendidik belum pernah melakukan khusus tes kemampuan berpikir kreatif dan khusus tes gaya belajar itu sendiri.

Peserta didik memiliki tingkat kemampuan berpikir kreatif matematis yang berbeda-beda dalam menyerap, menerima dan mengembangkan informasi yang diperolehnya ketika menyelesaikan persoalan matematika. Hal ini didukung dengan pendapat Siswono bahwa kemampuan berpikir kreatif seseorang memiliki level, level yang dimaksud dapat terlihat dari karya atau produk yang dihasilkan sesuai dengan indikator berpikir kreatif yang dicapainya, untuk tingkat 0 dikategorikan tidak kreatif karena dalam pemecahan masalah tidak mampu menunjukkan indikator kefasihan, fleksibelitas dan kebaruan. Untuk tingkat 1 dikategorikan kurang kreatif karena dalam pemecahan masalah hanya mampu memunculkan indikator kefasihan saja. Untuk tingkat 2 dikategorikan cukup kreatif karena dalam pemecahan masalah mampu memunculkan indikator fleksibelitas atau kebaruan saja. Untuk tingkat 3 dikategorikan kreatif karena dalam pemecahan masalah mampu memunculkan indikator kefasihan dan fleksibelitas atau kefasihan dan kebaruan. Dan untuk tingkat 4 dikategorikan sangat kreatif karena dalam pemecahan masalah mampu memunculkan tiga indikator yaitu kefasihan, fleksibelitas dan kebaruan (Santoso, Ratu, \& Yunianta, 2014).

Adapun menurut silver di dalam Muthaharah, Kriswandani, \& Prihatnani (2018) yang dimaksud dengan Kefasihan (fluency) adalah indikator yang dimiliki peserta didik di mana ia mampu menyelesaikan masalah matematika dengan bermacam-macam solusi dan jawaban dengan benar. Fleksibelitas (fleksibelity) merupakan indikator yang dimiliki peserta didik di mana ia mampu menyelesaikan masalah matematika dengan satu cara kemudian dalam cara lain dan peserta didik mendiskusikannya dengan berbagai metode penyelesaian atau dapat dikatakan peserta didik mampu menggunakan cara yang berbeda. Kebaruan (Novelty) merupakan indikator yang dimiliki peserta didik di mana ia mampu menyelesaikan masalah matematika dengan jawaban yang berbeda tetapi bernilai benar dan satu jawaban yang tidak biasa digunakan oleh peserta didik lainnya. Kekreatifan peserta didik ketika menyelesaikan persoalan matematika, dan dalam mencapai keberhasilannya dapat dipengaruhi oleh faktor gaya belajar yang dimiliki peserta didik itu sendiri (Rohmah, Rochaminah, \& Idris, 2017). 
Gaya belajar adalah Suatu hal penting yang harus diketahui oleh peserta didik karena berguna untuk mengembangkan kualitas pekerjaan yang disesuaikan dengan keadaan peserta didik sehingga ketika peserta didik mengetahui bagaimana ia memperoleh informasi kemudian menyerap informasi tersebut maka peserta didik akan lebih mudah menjadikan berkomunikasi dan belajar (Hasrul, 2009). Pendapat Hasrul serupa dengan pendapat Gunawan bahwa dalam melakukan kegiatan berpikir, memproses dan mengerti informasi peserta didik memiliki cara yang lebih disukainya itulah yang dimaksud dengan gaya belajar (Amir, 2015).

Secara umum didalam diri peserta peserta didik memiliki gaya belajar visual, auditory dan kinestetik. Untuk gaya belajar seseorang yang mengandalkan kemampuan indera penglihatan itu dinamakan gaya belajar visual, gaya belajar gaya belajar seseorang yang mengandalkan kemampuan indera pendengaran dinamakan gaya belajar auditory, dan gaya belajar seseorang dengan kemampuan fisik, pergerakan, atau sentuhan dinamakan gaya belajar kinestetik (DePorter \& Hernacki, 2016). Dan diantara ketiganya setiap peserta didik pasti memiliki gaya belajar yang berbeda, dan ada pula yang sama.

Beberapa penelitian yang telah dilakukan tentang berpikir kreatif menunjukkan peserta didik memiliki proses dan kemampuan berpikir kreatif yang berbeda-beda dalam menyelesaikan soal Open Ended (Fardah, 2012) dan penelitian lain menunjukan pula bahwa tingkat berpikir kreatif dan karakteristik peserta didik yang berbeda yang terlihat pada tiap proses berpikir kreatifnya dalam memecahkan masalah (Machromah, Riyadi, \& Usodo, 2015).
Hasil penelitian lain yang telah dilakukan mengenai gaya belajar peserta menunjukkan bahwa gaya belajar auditori mampu memecahkan masalah melalui tahap memahami, merencanakan, melaksanakan, kemudian memverifikasi kembali jawaban yang dihasilkannya (Rohmah et al., 2017). Penelitian ini melakukan kerterbaharuan yaitu melihat level berpikir kreatif di materi bilangan pecahan di tempat yang berbeda.

Selain materi dan tempat penelitian yang berbeda, penelitian terdahulu memang sudah membahas tentang tingkat kemampuan berpikir kreatif dengan tinjauan yang berbedabeda dan hanya tentang gaya belajar auditory saja, akan tetapi dalam penelitian ini akan meneliti gabungan antara berpikir kreatif dan gaya belajar(visual, auditorial, dan kinestetik) dengan criteria disetiap gaya belajarnya memiliki kemampuan matematika yang berbeda yaitu tingkatan tinggi dan rendah.

Berdasarkan uraian yang telah dijelaskan maka tujuan penelitian ini adalah untuk mengetahui bagaimanakah tingkat kemampuan berpikir kreatif ditinjau dari gaya belajar visual, auditorial dan kinestetik.

\section{METODE PENELITIAN}

Jenis penelitian yang dilakukan dalam penelitian ini adalah deskriptif kualitatif. Pengambilan subjek pada penelitian ini adalah menggunakan teknik purposive sampling. Subjek yang digunakan dalam penelitian ini adalah peserta didik kelas VIIB dan VIIE di SMP Muhammadiyah 3 Bandar Lampung. Teknik Pengumpulan data yang digunakan dalam penelitian ini adalah tes, angket dan wawancara. Bentuk wawancara yang dilakukan adalah wawancara semistruktur. 
Instrumen dalam penelitian ini ada dua macam, yaitu instrumen utama dan instrumen bantu. Instrumen utama adalah peneliti sendiri, dan intrumen bantu yang terdapat dua macam instrumen, yaitu instrumen penentu gaya belajar dan instrumen tes soal berpikir kreatif matematis (essay) yang digunakan untuk melihat tingkat kemampuan berpikir kreatif matematis peserta didik. Instrument dalam penelitian ini dilakukan melalui experts judgement (penilaian yang dilakukan oleh para ahli). Dalam peneitian ini dilakukan penyebaran angket di kelas VIIB dan VIIE kemudian setelah diketahui gaya belajar yang dimiliki oleh peserta didik diambil 2 peserta didik untuk gaya belajar visual, 2 gaya belajar auditory dan 2 gaya belajar kinestetik melalui pertimbangan pendidik mengenai kemampuan matematikanya, kemudian kemampuan matematika yang diteliti adalah peserta didik dengan kemampuan matematika tinggi dan rendah dan kemampuan komunikasi yang sama.

Teknik analisis data yang digunakan dilakukan dalam tiga tahap, yaitu reduksi data penyajian data dan pengambilan kesimpulan analisis (Sugiyono, 2016). Validitas data dalam penelitian ini dilakukan dengan triangulasi teknik dan triangulasi waktu - Teknik yang digunakan dalam penelitian ini yaitu dengan membandingkan data-data yang dikumpulkan menggunakan metode tes dan wawancara dalam waktu yang berbeda dengan sumber yang sama.

\section{HASIL PENELITIAN DAN PEMBAHASAN}

Berdasarkan penggolongan gaya belajar yang dilakukan dikelas VIIB dan VIIE diperoleh 27 peserta didik dengan gaya belajar visual, 17 peserta didik gaya belajar Auditorial, 13 peserta didik dengan gaya belajar Kinestetik, 3 peserta didik dengan gaya belajar visual auditorial, 1 peserta didik gaya belajar auditorial kinestetik, 1 peserta didik visual kinestetik dan 1 peserta didik dengan gaya belajar visual-auditorialkinestetik. Pengambilan data dapat dilakukan setelah diperoleh 2 peserta didik dengan kemampuan matematika tinggi dan kemampuan matematika rendah disetiap gaya belajarnya. Adapun daftar nama peserta didik yang akan diteliti dalam penelitian ini dalam Tabel 1.

Tabel 1. Daftar Nama subjek penelitian

\begin{tabular}{c|lcc|c}
\hline No & Nama Peserta Didik & Kode & Gaya Belajar & Kriteria \\
\hline 1 & M.Osa Saputra & MO & Visual & Tinggi \\
2 & Radho Singgih Saputro & RS & Visual & Rendah \\
3 & Arif Ahmad B & AA & Auditorial & Tinggi \\
4 & Zoland Ryo F & ZR & Auditorial & Rendah \\
5 & Virliya Nuralifa & VN & Kinestetik & Tinggi \\
6 & M.Raffi Firdaus & MR & Kinestetik & Rendah
\end{tabular}

Setelah didapatkan subjek disetiap gaya belajarnya, maka peneliti akan melakukan tes berpikir kreatif dengan 4 digunakan pada tahap pertama dan 2 soal pada tahap kedua. soal untuk mengetahui kemampuan berpikir kreatif matematis peserta didik terletak pada level keberapa, 2 soal 


\section{Analisis data subjek Visual dengan Kemampuan matematika tinggi dengan kode subjek "MO"}

Data analisis hasil tes dan wawancara tahap I dan tahap II akan dirangkum pada Gambar 1 dan Tabel 2.

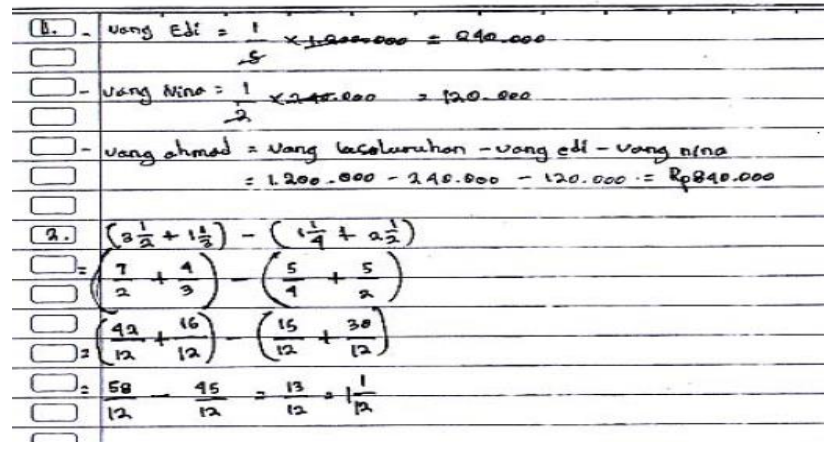

Gambar 1. Hasil Jawaban Subjek "MO"

Tabel 2. Data Analisis Tahap I dan Tahap II subjek "MO"

\begin{tabular}{ccccc}
\hline & Butir soal & Kefasihan & Fleksibelitas & Kebaruan \\
\hline Tahap I & $\mathbf{1}$ & $\sqrt{ }$ & - & - \\
& $\mathbf{2}$ & $\sqrt{ }$ & - & - \\
Tahap II & $\mathbf{1}$ & $\sqrt{ }$ & - & - \\
& $\mathbf{2}$ & $\sqrt{ }$ & - & -
\end{tabular}

Pada tes kemampuan berpikir kreatif matematis yang telah dilakukan di tahap I dan tahap II, Subjek "MO" mampu menjelaskan dan mengerjakan soal dengan jawaban yang benar dan gagasan yang ia tuangkan dijelaskan dengan pemikiran yang fasih dan lancar dalam menjawabnya. Subjek "MO" dalam menyelesaikan soal tersebut tidak memiliki cara yang lain karena cara yang dituliskan hanya menggunakan satu cara saja baik di nomor1 dan di nomor 2. Hal ini dikarenakan "MO" tidak terpikirkan menggunakan cara yang lain dan juga jika menggunakan cara yang lain cara penyelesainnya dianggap susah. Selain itu Subjek "MO" tidak memiliki cara yang bersifat baru karena cara yang dituliskan merupakan cara yang sudah umum dan sama dengan cara subjek lainnya. Walaupun tidak memiliki cara lain subjek "MO" dalam menyelesaikan soal tersebut mampu memahami maksud dari soal dengan membuat model matematika dari soal cerita dengan tepat dan konsep peritungannyapun dikerjakan dengan rinci dan tepat. Berdasarkan data tes dan wawancara yang telah dilakukan Ppada tahap I dan tahap II dapat disimpulkan bahwa subjek gaya belajar visual dalam klasifikasi berpikir kreatif menurut Siswono memiliki tingkat kemampuan berpikir kreatif tingkat ke-1 bahwa peserta didik dalam pemecahan masalah hanya mampu memunculkan indikator kepasihan saja.

\section{Analisis data subjek Visual dengan Kemampuan matematika rendah dengan kode subjek "RS" \\ Data analisis hasil tes dan} wawancara tahap I dan tahap II akan dirangkum pada Gambar 2 dan Tabel 3. 

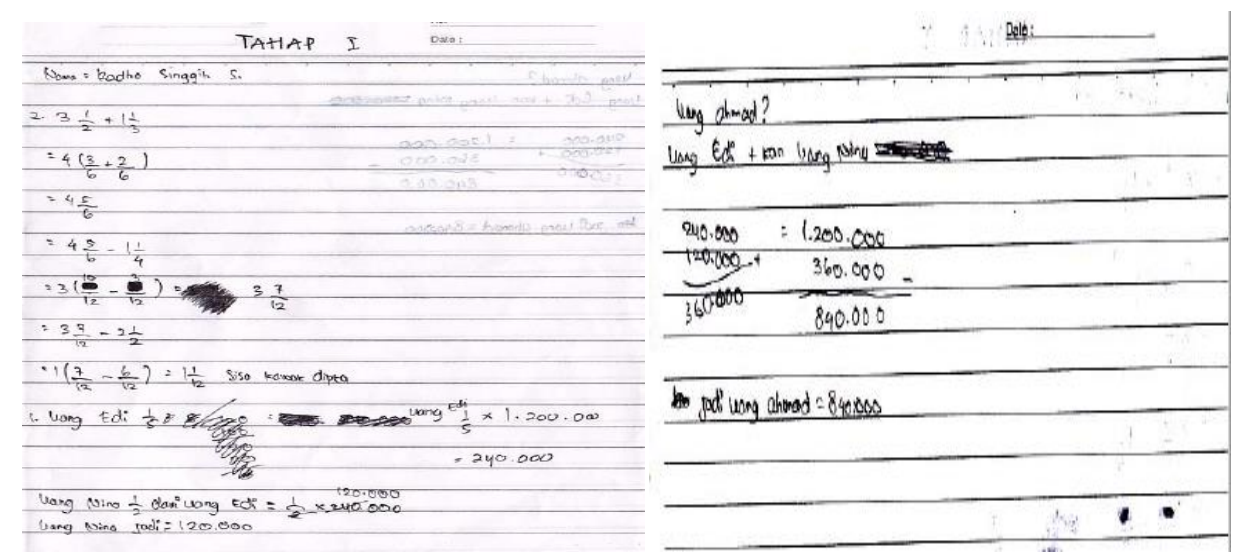

Gambar 2. Hasil Jawaban Subjek "RS"

Tabel 3. Data analisis Tahap I dan Tahap II subjek "RS"

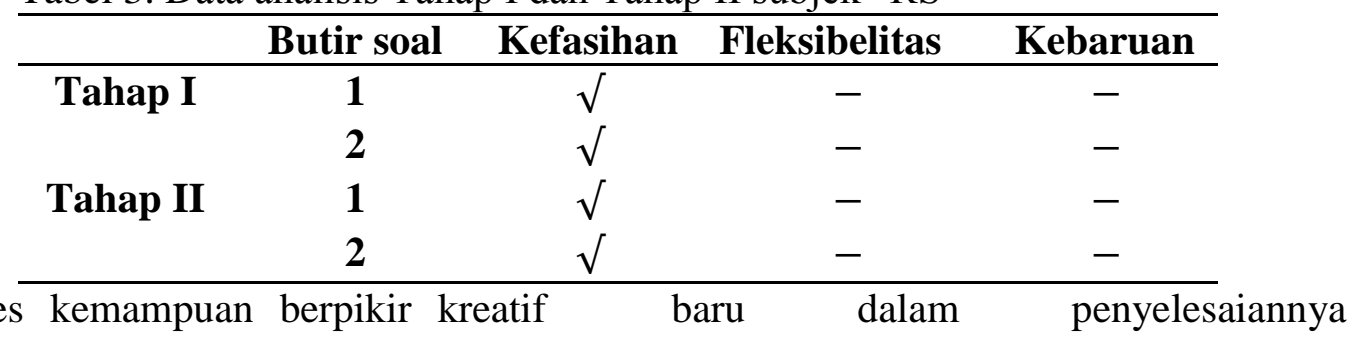

Pada tes kemampuan berpikir kreatif matematis yang telah dilakukan di tahap I dan tahap II, Subjek "RS" mampu menjelaskan dan mengerjakan soal dengan jawaban yang benar dan gagasan yang ia tuangkan dijelaskan dengan pemikiran yang fasih dan lancar dalam menjawabnya. Subjek "RS" dalam menyelesaikan soal tersebut tidak memiliki cara yang lain karena cara yang dituliskan hanya menggunakan satu cara saja baik di nomor 1 dan di nomor 2. Subjek "RS" tidak memiliki cara yang bersifat baru karena cara yang dituliskan merupakan cara yang sudah umum dan sama dengan cara subjek lainnya. Subjek "RS" mengerjakan soal tersebut penuh dengan ketelitian sehingga langkah demi langkah pada saat perhitungan menghasilkan jawaban yang benar, namun subjek "RS" tidak memiliki cara lain yang berbeda dan dikarenakan "RS" hanya fokus dan meyakini bahwa cara yang dituangkan adalah benar dan ketika diperintahkan mencari cara yang lain tetap saja subjek "RS" tidak mengetahui caranya.

Berdasarkan data tes dan wawancara yang telah dilakukan dapat disimpulkan bahwa subjek gaya belajar visual dalam klasifikasi berpikir kreatif menurut Siswono memiliki tingkat kemampuan berpikir kreatif tingkat ke-1 bahwa peserta didik dalam pemecahan masalah hanya mampu memunculkan indikator kepasihan saja.

\section{Analisis data subjek Auditorial dengan Kemampuan matematika Tinggi dengan kode subjek "AA" \\ Data analisis hasil tes dan} wawancara tahap I dan tahap II akan dirangkum pada Gambar 3 dan Tabel 4. 
DOI: https://doi.org/10.24127/ajpm.v8i1.1733
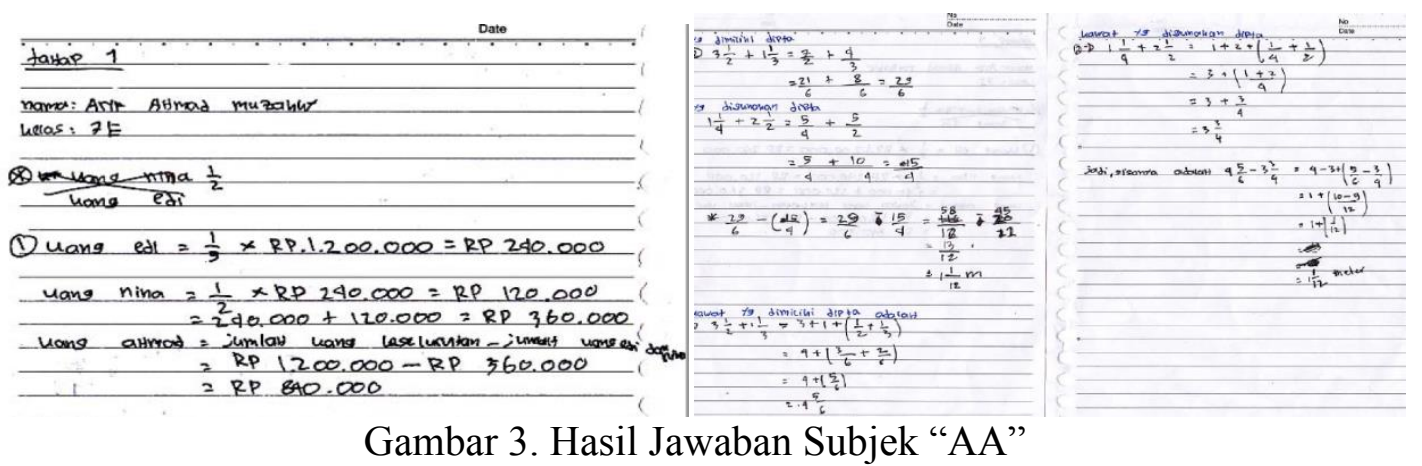

Gambar 3. Hasil Jawaban Subjek "AA"

Tabel 4. Data analisis Tahap I dan Tahap II subjek "AA"

\begin{tabular}{ccccc}
\hline & Butir soal & Kefasihan & Fleksibelitas & Kebaruan \\
\hline Tahap I & $\mathbf{1}$ & $\sqrt{ }$ & - & - \\
& $\mathbf{2}$ & $\sqrt{ }$ & $\sqrt{ }$ & - \\
Tahap II & $\mathbf{1}$ & $\sqrt{ }$ & - & - \\
& $\mathbf{2}$ & $\sqrt{ }$ & $\sqrt{ }$ & - \\
\hline
\end{tabular}

Pada tes kemampuan berpikir kreatif matematis yang telah dilakukan di tahap I, Subjek "AA" mampu menjelaskan dan mengerjakan soal nomor 1 dan nomor 2 dengan jawaban yang benar dan gagasan yang ia tuangkan dijelaskan dengan pemikiran yang fasih dan lancar dalam menjawabnya. Subjek "AA" dalam menyelesaikan soal soal nomor 1 tersebut tidak memiliki cara yang lain karena cara yang dituliskan hanya menggunakan satu cara karena "AA" menganggap mencari lain itu susah sedangkan di nomor 2 Subjek "AA" sangat merasa yakin atas jawaban yang dihasilkannya karena "AA" dapat menunjukkan dengan 2 cara yang hasilnya sama. Akan tetapi subjek "AA" tidak memiliki cara lain yang baru dalam menyelesaikan soal dikarenakan cara yang dituliskan merupakan cara yang sudah umum dan sama dengan cara subjek lainnya. Berdasarkan data tes
Tahap I dan tahap II yang telah dilakukan dapat disimpulkan bahwa subjek gaya belajar auditorial dengan kemampuan matematika tinggi pada umumnya dominan menunjukkan indikator kefasihan dalam memecahkan soal matematika artinya dalam klasifikasi berpikir kreatif menurut Siswono memiliki tingkat kemampuan berpikir kreatif tingkat ke-1 bahwa peserta didik dalam pemecahan masalah hanya mampu memunculkan indikator kepasihan saja.

\section{Analisis data subjek Auditorial dengan Kemampuan matematika Rendah dengan kode subjek " $\mathrm{ZR}$ " \\ Data analisis hasil tes dan wawancara tahap I dan tahap II akan dirangkum pada Gambar 4 dan Tabel 5.}


DOI: https://doi.org/10.24127/ajpm.v8i1.1733
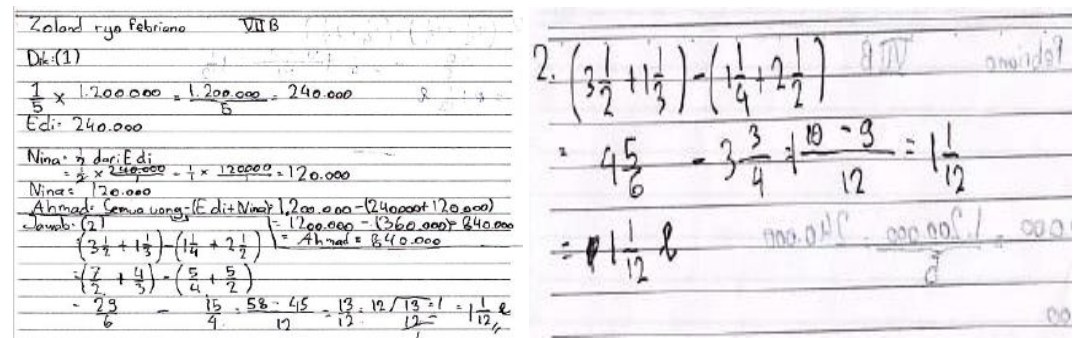

Gambar 4. Hasil Jawaban Subjek "ZR"

Tabel 5. Data analisis Tahap I dan Tahap II subjek "ZR"

\begin{tabular}{ccccc}
\hline & Butir soal & Kefasihan & Fleksibelitas & Kebaruan \\
\hline Tahap I & $\mathbf{1}$ & $\sqrt{ }$ & - & - \\
& $\mathbf{2}$ & $\sqrt{ }$ & $\sqrt{ }$ & - \\
Tahap II & $\mathbf{1}$ & $\sqrt{ }$ & - & - \\
& $\mathbf{2}$ & $\sqrt{ }$ & $\sqrt{ }$ & - \\
\hline
\end{tabular}

Pada tes kemampuan berpikir kreatif matematis yang telah dilakukan di tahap I dan Tahap II, Subjek "ZR" mampu menjelaskan dan mengerjakan soal nomor 1 dan nomor 2 dengan jawaban yang benar dan gagasan yang ia tuangkan dijelaskan dengan fasih dan lancar dalam menjawabnya. Subjek "ZR" dalam menyelesaikan soal soal nomor 1 tersebut tidak memiliki cara yang lain karena cara yang dituliskan hanya menggunakan satu cara sedangkan di nomor 2 Subjek "ZR" memiliki 2 cara yang berbeda dalam menyelesaikan soal tersebut. Akan tetapi subjek "ZR" tidak memiliki cara lain yang baru dalam menyelesaikan soal dikarenakan cara yang dituliskan merupakan cara yang sudah umum dan sama dengan cara subjek lainnya.
Berdasarkan data tes Tahap I dan tahap II yang telah dilakukan dapat disimpulkan bahwa subjek gaya belajar Auditorial dengan kemampuan matematika rendah pada umumnya dominan menunjukkan indikator kefasihan dalam memecahkan soal matematika artinya dalam klasifikasi berpikir kreatif menurut Siswono memiliki tingkat kemampuan berpikir kreatif tingkat ke-1 bahwa peserta didik dalam pemecahan masalah hanya mampu memunculkan indikator kepasihan saja.

5. Analisis data subjek Kinestetik dengan kemampuan matematika Tinggi dengan kode subjek "VN"

Data analisis hasil tes dan wawancara tahap I dan tahap II akan dirangkum pada Gambar 5 dan Tabel 6.

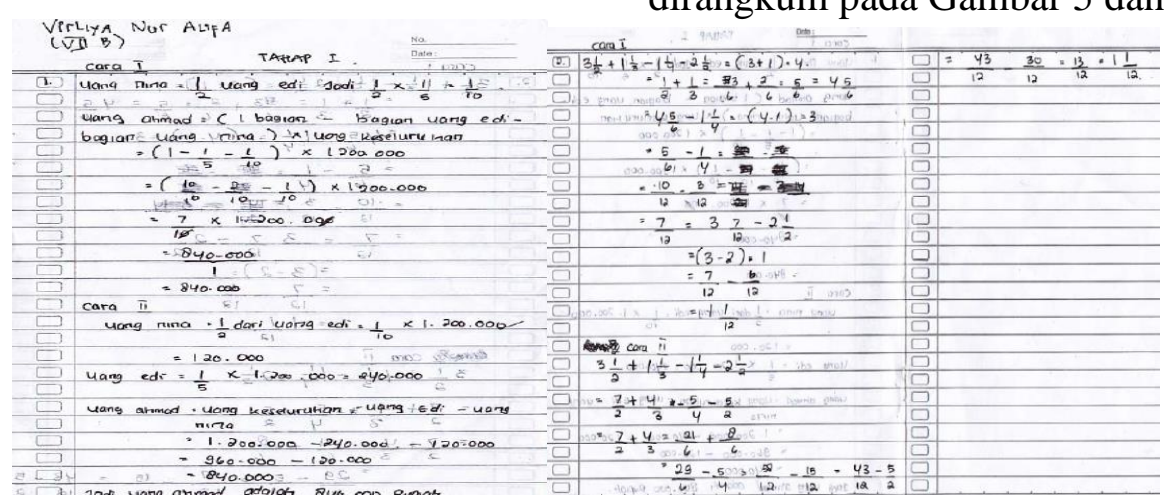

Gambar 5. Hasil Jawaban Subjek "VN" 
DOI: https://doi.org/10.24127/ajpm.v8i1.1733

Tabel 6. Data analisis Tahap I dan Tahap II subjek "VN"

\begin{tabular}{ccccc}
\hline & Butir soal & Kefasihan & Fleksibelitas & Kebaruan \\
\hline Tahap I & $\mathbf{1}$ & $\sqrt{ }$ & $\sqrt{ }$ & $\sqrt{ }$ \\
& $\mathbf{2}$ & $\sqrt{ }$ & $\sqrt{ }$ & - \\
Tahap II & $\mathbf{1}$ & $\sqrt{ }$ & $\sqrt{ }$ & $\sqrt{ }$ \\
& $\mathbf{2}$ & $\sqrt{ }$ & $\sqrt{ }$ & - \\
\hline
\end{tabular}

Pada tes kemampuan berpikir kreatif matematis yang telah dilakukan di tahap I dan tahap II, Subjek "VN" mampu menjelaskan dan mengerjakan soal nomor 1 dan nomor 2 dengan jawaban yang benar dan gagasan yang ia tuangkan dijelaskan dengan fasih dan lancar dalam menjawabnya. Subjek "VN" dalam menyelesaikan soal nomor 1 dan nomor 2 memiliki 2 cara yang berbeda dalam menyelesaikan soal tersebut . Selain itu subjek "VN" memiliki cara yang baru dalam menyelesaikan soal nomor 1 dikarenakan salah satu cara yang dituliskan tidak mampu dimunculkan oleh subjek lainnya sedangkan untuk disoal nomor 2 belum mampu menunjukkan kebaruan karena cara yang dituliskan sudah umum digunakan subjek lainnya. Dan hal ini telah dikonfirmasi pula bahwa dalam menyelesaikan soal "VN" hanya mampu memikirkan 2 cara saja.
Berdasarkan data tes Tahap I dan tahap II yang telah dilakukan dapat disimpulkan bahwa subjek gaya belajar Kinestetik dengan kemampuan matematika Tinggi pada umumnya dominan menunjukkan indikator kefasihan dan fleksibelitas dalam memecahkan soal matematika artinya dalam klasifikasi berpikir kreatif menurut Siswono memiliki tingkat kemampuan berpikir kreatif tingkat ke-3 bahwa peserta didik dalam pemecahan masalah hanya mampu memunculkan indikator kepasihan dan fleksibelitas.

\section{Analisis data subjek Kinestetik dengan kemampuan matematika rendah dengan kode subjek "MR"}

Data analisis hasil tes dan wawancara tahap I dan tahap II akan dirangkum pada Gambar 6 dan Tabel 7.

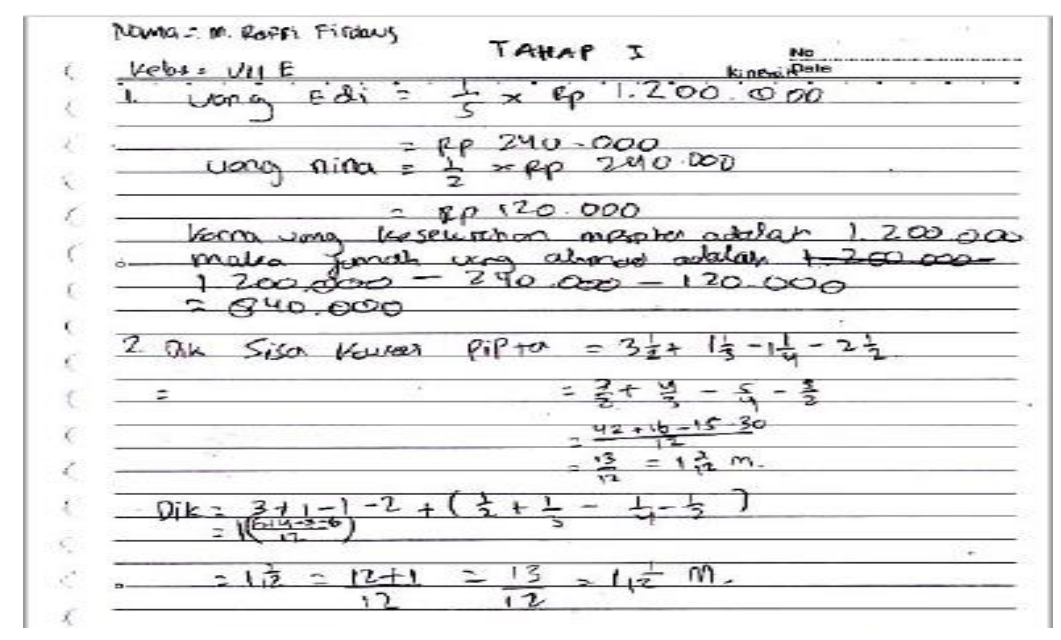

Gambar 6. Hasil Jawaban Subjek "MR" 
Tabel 7. Data analisis Tahap I dan Tahap II subjek "MR"

\begin{tabular}{ccccc}
\hline & Butir soal & Kefasihan & Fleksibelitas & Kebaruan \\
\hline Tahap I & $\mathbf{1}$ & $\sqrt{ }$ & - & - \\
& $\mathbf{2}$ & $\sqrt{ }$ & $\sqrt{ }$ & - \\
Tahap II & $\mathbf{1}$ & $\sqrt{ }$ & - & - \\
& $\mathbf{2}$ & $\sqrt{ }$ & $\sqrt{ }$ & - \\
\hline
\end{tabular}

Pada tes kemampuan berpikir kreatif matematis yang telah dilakukan di tahap I, Subjek "MR" mampu menjelaskan dan mengerjakan soal nomor 1 dan nomor 2 dengan jawaban yang benar dan gagasan yang ia tuangkan dijelaskan dengan fasih dan lancar dalam menjawabnya. Subjek "MR" dalam menyelesaikan soal soal nomor 1 tersebut tidak memiliki cara yang lain karena cara yang dituliskan hanya menggunakan satu cara sedangkan di nomor 2 Subjek "MR" memiliki 2 cara yang berbeda dalam menyelesaikan soal tersebut. Akan tetapi subjek "MR" tidak memiliki cara lain yang baru dalam menyelesaikan soal dikarenakan cara yang dituliskan merupakan cara yang sudah umum dan sama dengan cara subjek lainnya

Berdasarkan data tes Tahap I dan tahap II yang telah dilakukan dapat disimpulkan bahwa subjek gaya belajar Kinestetik dengan kemampuan matematika rendah pada umumnya dominan menunjukkan indikator kefasihan dalam memecahkan soal matematika, artinya dalam klasifikasi berpikir kreatif menurut Siswono memiliki tingkat kemampuan berpikir kreatif tingkat ke-1 bahwa peserta didik dalam pemecahan masalah hanya mampu memunculkan indikator kefasihan saja.

Penjelasaan-penjelasan diatas untuk tingkat kemampuan berpikir kreatif ke-1 memiliki hal yang sejalan dengan penelitian yang dilakukan oleh Ayuni, Firmansyah, Senjayawati, \& Maya (2018) tentang tingkat berpikr kreatif peserta didik pada materi lingkaran bahwa peserta didik di level satu telah mampu menyelesaikan permasalahan secara fasih akan tetapi peserta didik tersebut dikategorikan kurang kreatif karena dalam penyelesaiannya tidak memiliki cara yang berbeda dan baru ata unik. Dan hasil penelitian yang telah dilakukan oleh peneliti memiliki hal yang sejalan pula dengan penelitian yang dilakukan oleh Mulyaningsih \& Ratu (2018) mengenai tingkat berpikir kreatif peserta didik pada materi pola barisan, bahwa peserta didik dikatakan kurang kreatif karena dalam menyelesaikan permasalahannya sudah mampu memahami maksud soal dengan memberikan jawaban dan alasan yang benar dengan menggunakan satu cara sehingga peserta didik tersebut dapat disimpulkan mampu memunculkan indikator kefasihan saja.

Kemudian untuk tingkat kemampuan berpikir kreatif tingkat ke-3 memiliki hasil yang sama dengan penelitian yang dilakukan oleh Novianti \& Yunianta (2018) mengenai kemampuan berpikir kreatif pada materi Aljabar ditinjau dari perbedaan Gender bahwa peserta didik dengan kemampuan berpikir kreatif tingkat ke-3 adalah peserta didik yang mampu memenuhi indikator kefasihan dan fleksibelitas, dimana subjek mampu memahami maksud dari soal, dan peserta didik dapat menjelaskan langkah-langkah penyelesaian tersebut dengan benar. Selain itu peserta didik dapat menghasilkan lebih dari satu cara pula dalam menyelesaikan permasalahan. 


\section{KESIMPULAN DAN SARAN}

Berdasarkan hasil analisis data dapat disimpulkan bahwa peserta didik dengan subjek gaya belajar visual memiliki tingkat kemampuan berpikir kreatif kategori tingkat ke-1 (Kurang kreatif) karena dalam penyelesaian masalah hanya mampu memunculkan indikator kefasihan saja, sedangkan peserta didik dengan gaya belajar auditorial memiliki kesamaan dengan gaya belajar visual yaitu memiliki tingkat kemampuan berpikir kreatif kategori tingkat ke-1(kurang kreatif) karena dalam penyelesaian masalah hanya mampu memunculkan indikator kefasihan saja, dan untuk peserta didik dengan subjek gaya belajar kinestetik memiliki tingkat kemampuan berpikir kreatif kategori tingkat ke-3 (Kreatif) karena dalam penyelesaian masalah mampu memunculkan indikator kefasihan dan fleksibelitas dan tingkat ke-1 (Kurang kreatif) karena dalam penyelesaian masalah mampu memunculkan indikator kefasihan saja.

Berdasarkan kesimpulan tersebut dalam meningkatkan kemampuan berpikir kreatif matematis diharapkan pendidik dapat memberikan latihan diberbagai jenis soal yang dapat diselesaikan dengan banyak cara penyelesaian, pendidik diharapkan dapat menemukan dan mengembangkan cara belajar atau strategi belajar yang lebih bervariasi agar peserta didik yang memiliki perbedaan gaya belajar dapat mencapai kemampuan yang maksimal dalam memahami informasi. Serta untuk peneliti berikutnya hendaknya melakukan penelitian lebih lanjut mengenai berpikir kreatif dengan tingkatan sampel lebih banyak, pokok bahasan dan dengan tinjuan yang berbeda pula agar dapat dijadikan sumber pengetahuan dalam meningkatkan dan mengembangkan kompetensi berpikir kreatif matematis peserta didik.

\section{DAFTAR PUSTAKA}

Alhaddad, I. (2013). Penjenjangan Kemampuan Berpikir Kreatif dan Identifkasi Tahap Berpikir Kreatif Siswa Dalam Memecahkan dan Mengajukan Masalah Matematika. Delta-Pi: Jurnal Matematika Dan Pendidikan Matematika, 2(2), 5765.

Amir, M. F. (2015). Proses Berpikir Kritis Siswa Sekolah Dasar Dalam Memecahkan Masalah Berbentuk Soal Cerita Matematika Berdasarkan Gaya Belajar. JURNAL MATH EDUCATOR NUSANTARA: Wahana Publikasi Karya Tulis Ilmiah Di Bidang Pendidikan Matematika, 1(2), 159-170.

Anggoro, B. S. (2015). Pengembangan Modul Matematika Dengan Strategi Problem Solving Untuk Mengukur Tingkat Kemampuan Berpikir Kreatif Matematis Siswa. Pendidikan Matematika, 6(2), 123

Ayuni, R., Firmansyah, D., Senjayawati, E., \& Maya, R. (2018). Analisis Tingkat Kemampuan Berpikir Kreatif Siswa Dalam Menyelesaikan Permasalahan pada Materi Lingkaran. Jurnal Matematics Paedagogic, II(2), 139-148.

DePorter, B., \& Hernacki, M. (2016). Quantum Learning Membiasakan Belajar Nyaman Dan Menyenangkan. Bandung: Penerbit Kaifa.

Fardah, D. K. (2012). Analisis Proses dan Kemampuan Berpikir Kreatif 
DOI: https://doi.org/10.24127/ajpm.v8i1.1733

Siswa dalam Matematika Melalui Tugas Open-Ended. Kreano, Jurnal Matematika KreatifInovatif, 3(2).

Hasrul. (2009). Pemahaman Tentang Gaya Belajar. Jurnal MEDTEK, 1(2).

Machromah, I. U., Riyadi, \& Usodo, B. (2015). Analisis Proses dan Tingkat Berpikir Kreatif Siswa SMP dalam Pemecahan Masalah Bentuk Soal Cerita Materi Lingkaran Ditinjau dari Kecemasan Matematika. Jurnal Pembelajaran Matematika, 3(6),613-624.

Mulyaningsih, T., \& Ratu, N. (2018). Analisis Kemampuan Berpikir Kreatif Siswa SMP dalam Memecahkan Masalah Matematika pada Materi Pola Barisan Bilangan. Jurnal Ilmiah Pendidikan Matematika, 3(1).

Munandar, U. (2012). Pengembangan Kreativitas Anak Berbakat. Jakarta: Rineka Cipta.

Mursidik, E. M., Samsiyah, N., \& Rudyanto, H. E. (2015). Kemampuan Berpikir Kreatif Dalam Memecahkan Masalah Matematika Open-Ended Ditinjau dari Tingkat Kemampuan Matematika pada Siswa Sekolah Dasar. PEDAGOGIA: Jurnal Pendidikan, 4(1), 23-33.
Muthaharah, Y. A., Kriswandani, \& Prihatnani, E. (2018). Analisis Kemampuan Berpikir Kreatif Matematis Siswa Smp Dalam Menyelesaikan Soal Bangun Ruang Sisi Datar. E-Jurnal Mitra Pendidikan, 2(1), 63-75.

Novianti, F., \& Yunianta, T. N. H. (2018). Analisis Kemampuan Berpikir Kreatif Siswa SMP Dalam Menyelesaikan Soal Matematika Pada Materi Bentuk Aljabar Yang Ditinjau Dari Perbedaan Gender. MAJU: Jurnal Ilmiah Pendidikan Matematika, 5(1), 120-132.

Rohmah, Z., Rochaminah, S., \& Idris, M. (2017). Profil Pemecahan Masalah Matematika Siswa Smp Islam Terpadu Qurota A'yun Palu Ditinjau Dari Gaya Belajar Auditory. Jurnal Elektronik Pendidikan Matematika Tadulako, 4(4).

Santoso, H. R. W., Ratu, N., \& Yunianta, T. N. H. (2014). Deskripsi Tingkat Kemampuan Berpikir Kreatif (TKBK) pada Materi Segiempat Siswa Kelas VII SMP Negeri 1 Pabelan Kabupaten Semarang. Satya Widya, 30(2).

Sugiyono. (2016). Metode Penelitian Pendidikan (Pendekatan Kuantitatif, Kualitatif, dan $R \& D)$. Bandung: Alfabeta. 